\title{
Erratum to: Willingness to participate and Pay for a proposed national health insurance in St. Vincent and the grenadines: a cross-sectional contingent valuation approach
}

Rosmond Adams ${ }^{1}$, Yiing-Jenq Chou ${ }^{2}$ and Christy $\mathrm{Pu}^{2^{*}}$

Upon publication of this article [1] it has been noted that the acknowledgement section was missed out. It should read as below:

\section{Acknowledgments}

This study was funded by the Ministry of Science and Technology (former National Science Council), Taiwan (grant number: 102-2314-B-010-015-MY3).

\section{Author details}

${ }^{1}$ Ministry of Health, Wellness and Environment, Ministerial Building, Halifax Street, Kingstown, St. Vincent and the Grenadines. ${ }^{2}$ Department of Public Health, National Yang Ming University, 155, Sec.2, Linong Street, Taipei 112, Taiwan.

Received: 16 February 2016 Accepted: 16 February 2016

Published: 23 February 2016

\section{References}

1. Adams R, Chou Y-J, Pu C. Willingness to participate and Pay for a proposed national health insurance in St. Vincent and the grenadines: a cross-sectional contingent valuation approach. BMC Health Serv Res. 2015;15:148.

\footnotetext{
* Correspondence: cypu@ym.edu.tw

${ }^{2}$ Department of Public Health, National Yang Ming University, 155, Sec.2, Linong Street, Taipei 112, Taiwan

Full list of author information is available at the end of the article
}

Submit your next manuscript to BioMed Central and we will help you at every step:

- We accept pre-submission inquiries

- Our selector tool helps you to find the most relevant journal

- We provide round the clock customer support

- Convenient online submission

- Thorough peer review

- Inclusion in PubMed and all major indexing services

- Maximum visibility for your research

Submit your manuscript at

www.biomedcentral.com/submit 